\title{
ERRATUM
}

\section{Thailand's Kra Isthmus and Elusive Canal Plans since the I850s - ERRATUM}

\section{Stephen Dobbs}

doi: http://dx.doi.org/10.1017/trn.2015.27, Published by Cambridge

University Press, 9 December 2015.

The first sentence of the above publication (Dobbs 2016: 165) incorrectly listed the geographical region "Isthmus of Kra" in lowercase form "isthmus of kra" due to a typographical error. We apologize for this oversight.

\section{Reference}

Dobbs, Stephen. 2016. Thailand's Kra Isthmus and Elusive Canal Plans since the 1850s. Trans-Regional and-National Studies of Southeast Asia 4(1), 165-186. doi:10.1017/ $\operatorname{trn} .2015 .27$. 